\title{
Czesław Miłosz and Jerzy Andrzejewski: The Holocaust as Catholic Moral Crisis
}

\begin{abstract}
Brenner Rachel, Czestaw Miłosz and Jerzy Andrzejewski: The Holocaust as Catholic Moral Crisis, "Poznańskie Studia Slawistyczne" 16. Poznań 2019. Publishing House of the Poznan Society for the Advancement of the Arts and Sciences, Adam Mickiewicz University, pp. 295-318. ISSN 2084-3011.
\end{abstract}

This article examines the wartime texts produced by two deeply believing Catholics - Jerzy Andrzejewski and Czesław Miłosz. In 1942, at the time of the deportations to Treblinka, these young but already prominent Warsaw men of letters and believing Catholics engaged in a correspondence which examined the ethical crisis of the Jewish genocide and its impact on Christian humanism. Miłosz and Andrzejewski followed their epistolary exchange with literary responses to the 1943 Ghetto Uprising. Whereas the letters conceptualized possibilities of moral restoration, the literary works - Miłosz's two poems, Campo di Fiori and Biedny Chrześjanin patrzy na getto (A Poor Christian Looks at the Ghetto) and Andrzejewski's novella Wielki Tydzien (Holy Week) - focused on the devastating impact of the Jewish genocide on their Polish Catholic world. These literary works see the event of the Holocaust as an irrevocable failure of the Catholic dogmas of caritas and love for the Other.

KeYwords: Holocaust; Catholicism; genocide; humanism; ethics

\section{Introduction}

Recent political and ideological developments in Poland seem to have thwarted the long overdue need for a reassessment of Polish collective behavior at the time of the Holocaust. The present right-wing Polish government has, in fact, embarked on an extensive program of revisionist history. ${ }^{1}$ It has also engaged in a vigorous campaign aimed at superseding

${ }^{1}$ Thus the Polish Minister of Education, Anna Zalewska, claimed, "Różne były zawiłości historyczne w pogromie kieleckim." (In the Kielce pogrom there were various historical complexities). "Jedwabne to fakt historyczny, w którym doszło do wielu nieporozumień, do 
the negative historical findings with an alternative history of the selfless and compassionate help that wartime Catholic Poles allegedly extended to Jews. In particular, the proliferation of commemorative monuments in Poland dedicated to Polish rescuers of Jews demonstrates the intensity of the government's desire to rewrite history in the spirit of the Catholicism as an indelible component of the Polish national identity. The recently inaugurated Chapel of the Righteous (Kaplica Sprawiedliwych) in Torun and the collection of Polish rescuers managed primarily by the Church evinces the religious aspect of the present-day intention to rewrite the Polish history of the Holocaust (Chmielewska, Molisak, 2017, 53). This trend has been met with a plethora of historical research that exposes the ideological manipulation of historical document and artifacts.

The modern controversy over Polish-Jewish historical memory underscores the importance of real-time Polish literary responses to the Holocaust. Ideologically motivated revisionist history can be challenged not only by contemporary historians, but also by the Polish writers who eye-witnessed the conduct of Poles toward Jews during the war and documented it in their immediate literary responses. The historical proximity of the texts to the events they depict vouches for their factual accuracy, while their prevailing tenor of self-reproach attests to the writers' emotional sincerity as they struggled with the moral consequences of witnessing an atrocity. These literary testimonies provide compelling evidence that cannot be ignored.

This article examines the wartime texts produced by two deeply believing Catholics - Jerzy Andrzejewski and Czesław Miłosz. In 1942, at the time of the deportations to Treblinka, these young but already prominent Warsaw men of letters and believing Catholics engaged in a correspondence ${ }^{2}$ which examined the ethical crisis of the Jewish genocide and its impact on Christian humanism. Miłosz and Andrzejewski followed their epistolary exchange with literary responses to the 1943 Ghetto Uprising. Whereas the letters conceptualized possibilities of moral restoration, the literary works - Miłosz's two poems, Campo di Fiori and Biedny Chrześjanin patrzy na getto (A Poor Christian Looks at the Ghetto) and

wielu bardzo tendencyjnych opinii." (Jedwabne is a historical fact that brought forth many misunderstandings, many biased opinions.) http://www.tvn24.pl. 13.07.2017.

${ }^{2}$ They were actually exchanging the letters in a café. 
Andrzejewski's novella Wielki Tydzien' (Holy Week) - focused on the devastating impact of the Jewish genocide on their Polish Catholic world. In these literary works, they boldly denounced their fellow-Poles indifference to the Jewish plight, acquiescence with the Jewish extermination, and refusal to shelter Jews.

The traumatic experience of watching the moral deterioration of their human environment was intensified by both writers' adherence to the Catholic existentialist theology of personalism, a movement which was popular in interwar Poland (Andrzejewski, 1987). Personalism emphasized individual freedom and responsibility for one's actions, and placed the dignity of the person at the center of their moral system (v., for instance, Austin, 2013). In contrast with the Church's traditional focus on the afterlife and the salvation of the soul, these Catholics promoted the neo-Thomist perception of existence in the here and now and saw salvation in fraternal contacts with others (v., for instance, "Personalism" in Stanford Encyclopedia of Philosophy, and Rourke, Chazarreta Rourke, 2007). They insisted that the authenticity of Christian faith consisted in the conscious recognition of Grace in the commonality and dignity of all human beings (Williams, 2004; v. also, Wojtyła, 1963, 8-9).

In this sense, the novum of the Jewish genocide threatened to discredit the writers' faith in the ethics of human dignity grounded in the inherent moral potential of the human nature that informed the philosophical and theological perceptions of humanity throughout history. As we shall see in Miłosz's and Andrzejewski's letters, both writers were struggling with the vanishing evidence of anamnesis, that is, the Platonic assertion of knowledge before knowledge, which postulates "that the human soul can recall what she once knew about virtue and other things" (Allen, 1959, 165). The belief in the better nature of human beings, which affirms the ideal Forms in the "particulars," everyday occurrences (Allen, 1959, 171-172).

Perhaps even more traumatic was the related realization of the disintegration of the axiomatic a priori ethical principles that inform both Jewish and Christian theologies. ${ }^{3}$ Thus, the proscriptions of the Ten Commandments assume an a priori moral capacity of human beings. The

${ }^{3}$ These moral principles exist in other religions as well, such as Islam, but since the Holocaust involved Jews and Christians, I refer to the Jewish and Christian traditions. 
prohibition of murder indicates that while human beings have the capacity to murder other human beings, they also have the capacity to refrain from murdering others. Similarly, the concept of imitatio Christi, which commands emulation of the Savior's love for humankind, arises from faith in human moral essence. The Christian tenet of caritas epitomized in the dictum "love your neighbor" surmises that human beings are capable of caring selflessly for their fellow human beings.

The biblical moral tradition of both religions presupposes the ethical essence of human existence, which is capable of governing its proneness to sinfulness. The fact that the reality of the Jewish genocide, which collapsed the fundamental right to dignity and the sanctity of life of all human beings, was accepted and often approved by the Polish Catholic mainstream affected the writers most personally. As their literary writings show, it made them recognize the devastating truth that the moral failure of their fellow Catholic Poles tarnished them as moral human beings.

\section{Miłosz and Andrzejewski's Correspondence during the Occupation}

During the summer and fall of 1942, at the time of the mass deportations of the Jews to Treblinka, Czesław Miłosz (1911-2004) and Jerzy Andrzejewski (1909-1983) engaged in a remarkable epistolary exchange that addressed the present-day situation (Miłosz, 2005). ${ }^{4}$ The writers recognized that the violence of the occupation and the premeditated destruction of the Jews had transformed the world as they knew it. They feared the irreversible impact of this morally corrupt ideology on human society and shared the view that the unprecedented eruption of genocidal evil disempowered the norms of Christian humanistic ethics, and, more specifically, the teachings of the Catholic Church.

Miłosz acknowledged the unprecedented situation whereby "evil... revealed itself in all grandeur; it surpassed expectations and analysis" (Miłosz, 2005, 150). He observed that the new situation exposed "the elasticity of human nature" which enabled transgression of the ethical principle

\footnotetext{
${ }^{4}$ Page numbers of the quotations appear in the text.
} 
"as old as culture that can be traced back to ancient Greece." Even though called by various names, such as "reason, daimonion, common sense, the categorical imperative, the moral instinct" (Miłosz, 2005, 174), this moral principle has always signified the universal moral ideal of the equality of all human beings. The universal concept of civilization, which was built on the "belief in the similarity of human nature, irrespective of race, religion, and language, belief in the identical moral sense and similar definition of good and evil," has proven to be "the last of the world delusions." He noted how "the extermination of people in camps, in prisons" (Miłosz, 2005, 175) abolished the "classification of murder as an ugly act" by eliminating "pangs of conscience" and "the issue of guilt." Alluding to the arbitrariness of Jewish life and death in a reality informed by the new moral principle of racist categorization, Miłosz stated that "Today, the issue of guilt is fading" and so " $\mathrm{X}$ dies... because of his hair color, the shape of his nose, or his parents' background" (Miłosz, 2005, 177). The Jews are branded as "enemies of the human race, subhumans, and as such, they are released from the prescription of the ethics" (Miłosz, 2005, 179). Indeed, the principles of ethics are being redefined "when certain groups of people are bracketed out" of human society and are condemned to death. The new moral order enables "a German, a model son, husband, loving father of a family [to] torment a subhuman... because he is obsessed with his vision of duty and justice, which commands him to cleanse Europe from similar vermin" (Miłosz, 2005, 181).

Miłosz admitted that the pernicious experimentation with human life in the "great laboratory of time between 1939 and 1942" made him aware of the changing "river of history" (Miłosz, 2005, 247). The hitherto immutable ethical foundations of human existence have been swept away by the new historical current. In a situation whereby "evil has become complicated... more clever and sly," the trust that "the world has been standing still since the beginning of time [and] that the selfsame proportions of good and evil exist now as they existed in the time of Cain and Abel" (Miłosz, 2005, 235) has become untenable. The disintegration of everything we believed in transformed Catholicism into "a desiccated mummy" (Miłosz, 2005, 152) which denoted "the impossibility to remain Catholic" (Miłosz, 2005, 211). Similarly, the "best ethical canon" of the Ten Commandments has broken down, because the new ethics which decreed murder of innocent people 
has rendered the injunction "thou shalt not kill" obsolete (Miłosz, 2005, 236-237). ${ }^{5}$ As Miłosz sees it, the age of "the disappearance of the criteria of truth other than the criterion of utility" has eliminated the religious "tradition that acknowledges the superiority of good over evil" (Miłosz, 2005, 250). Thus, at the time when people are murdered because of their ethnic identity, the religious dictates of goodness and compassion have become meaningless.

In place of these discredited religious tenets, Miłosz proposes a selfconscious, socially engaged intellectualism that recognizes its own uncertainty and doubt. In the reality of extermination camps, intellectualism, which "will undertake education," may "soften the absurdity of the collective urges" and the "spontaneous passions" of "the masses" whose irrationality encourages "tyranny" (Miłosz, 2005, 253). In the era of unaccountable brutality, humanity is obligated to devise strategies to curb its own destructive impulses through education reaffirming rational thinking. ${ }^{6}$

Miłosz argued that education toward rational behavior would be performative: it will change reality by instigating "that great act of returning dignity to man after so much blundering in the forest of instincts" (Miłosz, $2005,254)$. He recognized the precariousness of reason as a redemptive force, whereby the current moral crisis created a "modus of indecision," which made equally possible the continuation of "the purification of mankind through suffering and blood" and the realization "that man is worn down by cruelty and freedom of instincts" (Miłosz, 2005, 257, emphasis in the text). Nonetheless, hope for moral restoration lies in an effective education that would stall the irrational impulses with the power of reason.

Andrzejewski concurred with Miłosz's view of the emergence of evil that collapsed the belief in the inherent moral nature of humankind. The new reality of the "boundlessness of human suffering and the equal boundlessness of the most despicable human instincts" cannot be ignored, nor can it be evaded. Andrzejewski, asserted the impossibility of disregarding even

${ }^{5}$ The literal translation of the original Hebrew is "Thou shalt not murder."

${ }^{6}$ Miłosz's reasoning, which attributes the breakdown of the humanistic civilization to an instinctual, irrational upheaval of the masses, echoes Freud's postulation in his 1929 Civilization and Its Discontents, "civilized society is perpetually threatened with disintegration [...] instinctual passions are stronger than reasonable interests. Civilization has to use its utmost efforts in order to set limits to man's aggressive instincts". 
geographically distant suffering, because "imagination... inclines us to pay distressed attention even to those human voices whose whisper or scream resounds far away from us on battlefields, in prisons, in the camps" (Miłosz, 2005, 160-161). His sensitivity to human suffering made him long for some form of reassurance and a degree of mental stability: "I find myself yearning to achieve at least a scrap of knowledge that would solidify the ground under my feet and give solace to my gaze" (Miłosz, 2005, 161). However, the victorious forces of evil won't let him maintain his faith in the universality of human "fraternity" and "solidarity." The prevailing racist ideology has redefined solidarity and fraternity in terms of the radical exclusion of others. The ease with which moral values have been superseded by the fascist ideology evinced the inadequacy of the humanistic system of ethics; it revealed "that the concept of a moral law is still too little to unite humanity with a real and permanent bond" (Miłosz, 2005, 170-171).

Today's persecutions of the Jews, claims Andrzejewski, defy "Lessing's famous saying that 'everything has already happened."' Indeed, persecutions of Jews are not new in human history. But even though the suffering of the Jews inflicted by the "Holy Inquisition" must be acknowledged, the purpose and intention of the Inquisitors cannot be placed "in the same category as the judges who pronounce their sentences in the shadow of the swastika" (Miłosz, 2005, 188). While human suffering cannot be rated, or relativized, it is "the changeability of the intentions" that differentiates between the former forms of victimization of Jews and their present-day murder "in the name of the superiority of the German race, [which] makes a contemporary German into a fervent exterminator of "subhumans"' (Miłosz, 2005, 190).

Like Miłosz, Andrzejewski recognized the superior powers of evil when he claimed, "we will certainly agree that evil brings us a reality that is incomparably more crystalized than good," and that "many of those who yearn for the restoration of human order speak about it more vaguely, with less precision, than those who thought up the concentration camps and the mass slaughter of defeated peoples" (Miłosz, 2005, 239-240). And so, like Miłosz, he confessed not to be "strong enough to create a new Ten Commandments" (Miłosz, 2005, 242).

Nonetheless, Andrzejewski did not concur with Miłosz's perception of Catholicism as "a desiccated mummy," which, he noted, indicated Miłosz's 
refusal to make an attempt "at resolving man's problems on the plane of religion" (243). He rejected Miłosz's search for resolution of the moral crisis in intellectualism, which, he claimed, was self-conscious and therefore self-doubting. As he saw it, Miłosz's proposed solution to the ethical crisis denoted a vicious circle: employing intellect to deal rationally with present-day humanity's uncertain moral direction cannot offer any reliable solution since, by virtue of its self-conscious and speculative nature, intellect produces uncertainty. "Intellectual exertion commands you to doubt," he tells Miłosz, and therefore, "striving to discover a new permanent ethical norm, you find a cognitive instrument instead. This is the intellect" (Miłosz, 2005, 245). In the idea of intellectualism there is "an element of desertion, of dry abstraction" (Miłosz, 2005, 241), which deprives the human soul of the emotional bond with humanity, and which can be restored only through re-cognition of the Church teachings.

Whereas Miłosz attributed the moral crisis to Catholicism's failure to keep human impulses in check and enforce the prohibition of murder, Andrzejewski saw the problem in the emergence of a "naturalistic man separated from his supernatural intercessor" (Miłosz, 2005, 244). Modernism, which effected spiritual estrangement from the Church, disavowed the commandment of love. The dismissal of love as a unifier and equalizer devalued human life and facilitated mass murder.

Confessing his "need to sustain the hope [that the relevance of the Church] is not yet lost" (Miłosz, 2005, 193), Andrzejewski reaffirmed his faith in Divine Providence. Even though he admitted, "I cannot fathom the meaning of this world," he claimed, "I know that a meaning exists, that it is circulating among us as like an invisible spirit" (Miłosz, 2005, 222). He asserted the importance of the Church for humanistic ethics, because "Christianity revealed in the figure of Christ the bonds between the absolute and the human tribe" (Miłosz, 2005, 196). At the same time, Andrzejewski admitted that he could not identify with the traditional aspects of the Church: "I do not feel at home with the concepts of dogma or in the ranks of religious orthodoxy" (Miłosz, 2005, 240). This realization made him seek the divine by developing love for the other through self-love.

Andrzejewski proposed a reading of the commandment "love your neighbor as thyself" that would promote the redemptive aspect of self-love. 
Proper self-love enables the affirmation of the equality and dignity of the other. It indicates the ability "to accept life in thought and deed," because true self-love enables "awareness of essential meaning of one's own existence." Self-love is a "wise love" and a "submissive love" because it relies on emotions that, unlike reason, privilege feelings over logic. Alluding to Paul's postulation about the virtues of faith, hope, and love (1 Corinthians 13:13), Andrzejewski declared self-love to be "trusting, because it carries within itself faith and hope," and in this sense "it unites with all people" (Miłosz, 2005, 224). Thus, loving self-acceptance engenders "respect for another person and consciousness of human loving relationships as a concept of an ethical norm" (Miłosz, 2005, 225), and therefore promises the restoration of moral law. ${ }^{7}$ Andrzejewski saw the return of human solidarity in cultivation of self-love and self-respect as God's creation, the origin of existence that one shares with humanity.

Miłosz and Andrzejewski's correspondence demonstrates that even though they were aware of the depth of the moral crisis they witnessed daily and even though they acknowledged the victory of the unleashed forces of evil, they could not altogether abandon their hope for moral restoration. Significantly, contrasting attempts of rejection and reaffirmation of the Catholic Church informed the writers' visions of the future. Miłosz ascribed the crisis to the Church's loss of authority and sought ethical restoration in a system of education, which would adopt the Enlightenment faith in the concept of reason. In contrast, Andrzejewski, who attributed the crisis to modernity's individualism and its abandonment of the Church community, conditioned ethical mending on collective return to the Church teachings of love.

Andrzejewski was convinced that the process of mending the world should not be deferred, but had become a moral imperative in the reality of genocide. As he wrote to Miłosz, "three full years of occupation," made him realize that "whether the earth moves forward or not also depends on us. On you, on me, on everyone alive" (Miłosz, 2005, 221). He claimed

${ }^{7}$ Before the war, Andrzejewski was considered a "Catholic writer." He was writing in the spirit of the existentialist-personalist-Catholic movement which claimed the centrality of the dignity of the human person. The concept of personalism was embraced by thinkers such as Jacques Maritain and Emmanuel Mounier, as well as by Karol Wojtyła, the future Pope John Paul II. 
that even though they did not bear responsibility for the "catastrophe," nonetheless, as witnesses, they bore responsibility for humanity's moral revival. Therefore, he impressed upon Miłosz that the situation "obligates us" to act so that "those voices of unchanging evil [may] not be the loudest" (Miłosz, 2005, 221).

Indeed, hardly a year later, Miłosz and Andrzejewski felt obligated to launch their literary voices against the voices of evil emanating from the fires of the Ghetto Uprising. While Miłosz only published the 1942 correspondence in 1990, admitting to have been persuaded "by those who argued for their [the letters'] archival value, since there are few testimonies about people's state of mind during the time of the German occupation" (262), his 1943 poems Campo di Fiori and Biedny chrześcijanin patrzy na getto (A Poor Christian Looks at the Ghetto), and Andrzejewski's 1943 novella, Wielki Tydzień (Holy Week), were written for immediate publication. ${ }^{8}$

One might expect both writers to have responded the liquidation of the Ghetto with incriminating representations of the Nazi perpetration of the Jewish Holocaust invoking the ethics of law and justice to counter the genocidal terror. Ironically, the site and the manner of the murder precluded such representations. The walls surrounding the Ghetto blocked the site of the crime from the outside world, and the immolation of the Ghetto and its Jewish inhabitants left no evidence of the crime and its perpetrators. The inability to either eye-witness the act of murder or to identify the murdered people imparted impunity to the murderers and the inability to redress injustice heralded a new order of genocidal ethics.

The concealment the crime notwithstanding, the consciousness of the Jewish tragedy, which reached the "aryan side" of Warsaw through the horrific black clouds of smoke and the terrifying sounds of fighting,

${ }^{8}$ Miłosz’s poems were published in his 1945 volume of poetry, Ocalenie (Warsaw: Spółdzielnia Wydawnicza „Czytelnik”); Campo di Fiori was published in 1944 in the volume Z otchłani: poezje, ed. L. Wajdelota [T. Sarnecki] (Warszawa: Wydaw. Ż.K.N. [Żydowskiego Komitetu Narodowego]); Andrzejewski read the first version of Holy Week to fellow-writers in 1943. The rewritten and only extant version of Holy Week was published in the 1945 collection of stories Noc (Warszawa: Spółdzielnia Wydawnicza "Czytelnik").The quotations are taken from the translation by Oscar E. Swan and his students (Miłosz, 2007). Page numbers from the translation will appear in the text. 
was bound to evoke an emotional response in the surrounding Polish population. Condemnation of the perpetrators and a compassionate identification with the Jews perishing behind the Ghetto walls would have singled out the Jewish genocide as an exclusively Nazi aberration that violated the normative humanist value system. In the Platonic schema of anamnesis, the "recollection" of Polish Catholics of Christian caritas in view of the misery of the Jewish "neighbor" would have reaffirmed the inherent virtues of the human soul. Such a moral response to the mass murder behind the Ghetto walls would have reaffirmed humanistic ethics and Catholic morality.

As the literary responses of Miłosz and Andrzejewski show, however, the mainstream Polish attitude did not register a repudiation of the crime. On the contrary, the scarcity of condemning voices and the frequently voiced approval of the Jewish extermination signaled acquiescence with the genocidal evil. Tragically, Miłosz's poems and Andrzejewski's novella demonstrate how the vitiating impact of the new genocidal ethics disproved the theological-philosophical premise of the a priori moral nature of human beings.

\section{Campo di Fiori and A Poor Christian Looks at the Ghetto: The Failure of Reason and the Defeat of Faith}

On the fiftieth anniversary of the Ghetto Uprising, Miłosz recalled the conception of Campo di Fiori:

This poem, like some others that were born of moral outrage and anger, was wrenched out of me through a coincidence. I was on my way to Andrzejewski... The tramline went right past where the merry-go-round stood and where you could hear the shots of the insurgents defending themselves... for a long time I looked at what was going on there. I wrote the poem soon afterwards, affected by that experience... (Błoński, Edelman, Miłosz, Turowicz, 2012).

The poet went on to explain the metaphor of "Campo di Fiori" and its association with the burning Ghetto:

For me the loneliness was the most important element here. The loneliness of the dying. After all that was the source of the image of Giordano Bruno. I don't know where the 
image came from, because it wasn't philosophical. It wasn't that Giordano Bruno was for me a hero of the fight for free thought. I remembered the Campo di Fiori, that place where Giordano Bruno was burnt, and the ceaseless bustle of people at the market, enjoying themselves all around (Błoński, Edelman, Miłosz, Turowicz, 2012, 417).

The poet's accounts of the genesis of Campo di Fiori reveal a certain incongruity. On the one hand, Miłosz's description of the poem being "wrenched" out of him in "moral outrage and anger" at the sight of the sky-carousel ${ }^{9}$ in front of the Ghetto walls portrays Campo di Fiori as an eruption of passionate, uncontrollable feelings. On the other hand, the use of the existential condition of the "loneliness of the dying" as a link between two historically and geographically remote and unrelated atrocities suggests a complex rationalization that questions the spontaneous conception of the poem.

In his 1983 conversations with Ewa Czarnecka, Miłosz called Campo di Fiori a "civic-minded poem" that "derived from moral indignation." At the same time, he also called it "a very immoral poem" since, as he explained, "it was written from the point of view of an observer of people who were dying," or rather, as a closer look at the poem reveals, that the poet was in fact observing people who were indifferent to people who were dying (Czarnecka, Fiut, 1987, 13, 131). Miłosz's harsh judgment of Campo di Fiori reflects, to paraphrase Sartre, the premise of la poésie engagée. Poetry has the moral obligation to respond empathically to the human condition in a particular historical moment and therefore the aesthetics of the poem should enhance its humanistic content. In the case of Campo di Fiori, the poem's standpoint failed to accord with the message. Rather than evoking an emotional identification with the sufferers, the objective perspective of an observer abstracted the experience of suffering.

Miłosz's view of mending the world in his correspondence with Andrzejewski sheds light on the poet's critical assessment of Campo di Fiori. From this perspective, the poem illustrates the poet's vision of the world's moral restoration in an intellectual and rational educational process. It exposes the morally flawed attitude of the witnessing population toward the Jewish genocide and proposes to mend it by way rational persuasion.

9 "Sky-carousel," which denotes swing ride, seems a better translation of karuzela than merry-go-round, where the riders spin around a vertical axis. 
Miłosz's harsh judgment of Campo di Fiori as immoral implies the poet's retraction of his position that sees hope for the world's moral restitution in rational re-education.

Indeed, the poem appraises the witnesses' responses to the tragedy of the Ghetto from a comparative, rationally conceptualized standpoint. The juxtaposition of the scenes on the Krasińskich Square in Warsaw in front of the Ghetto walls and on the Campo di Fiori in front of the burning stake of Giordano Bruno in sixteenth-century Rome attests to a carefully reasoned poem. The contrived symmetrical construction of the associative connection of the indifferent crowds in those scenes effectively quashes the initial, impulsive reaction of moral outrage, indignation, and anger that Miłosz recalled in the interviews. Indeed, the emphasis on the similarity of the Italian and Polish responses to human pain defuses the poet's anger at the response of his Polish compatriots to the Warsaw Ghetto tragedy. The comparative point of view allows him to reach a dispassionate, reason-based conclusion in which the Polish response of indifference to the Jewish tragedy represents a typical human attitude toward the suffering of humanity at large.

The poem consists of eight stanzas, each eight lines long. The first two stanzas describe the Campo di Fiori, where Giordano Bruno's execution interrupts only for a moment the crowd's preoccupation with shopping and selling goods on the square and eating and drinking in taverns. The subsequent two stanzas depict the scene, where "The salvos behind the ghetto walls/ were drowned in lively tunes," and where young couples were having fun flying up high on the sky-carousel among the "flying charred bits." The transitional lines, "I recalled Campo di Fiori/ in Warsaw by the sky-carousel," introduce the first-person speaker as a didactic poet who makes sure the reader understands the association he draws between the events in Rome and in Warsaw. In the next two stanzas the speaker-poet uses the rhetorical strategy of refutatio: he lists two possible lessons - the inherent human indifference to suffering and the transitoriness of human memory - that can be deduced from the juxtaposition of the crowds' responses to the suffering of Giordano Bruno and the Ghetto Jews. However, he rejects these lessons and discerns instead in both scenes the martyrs' estrangement from humanity. "But I that day reflected/ on the loneliness of the dying men." The concluding stanzas depict the common lack of interest in the misery of others. Preoccupied with satisfying their mundane needs and appetites, the crowds cannot 
bother to pay attention to the victims' language of loneliness and pain. But the poet does. Thanks to his empathic attention, the language of suffering, their story will become a "legend" when "the poet's word shall stir revolt/ on the new Campo di Fiori" (Polonsky, 1990). The poem thus concludes with a reassurance that the victims' suffering will be restored to collective memory, and thus that moral justice will prevail.

Campo di Fiori contrasts the commonplace response to suffering with the exceptionality of the poet's vision. Historical and circumstantial disparities notwithstanding, common folk will always focus on satisfying their need for bread and circuses. The poet, however, due to his intellectual superiority and ability to reason, will focus on the edifying potential of the situation. Assuming the traditional role of poets as visionary teachers and leaders of humanity, the speaker-poet envisages the transformative effects of paying attention to suffering. In fact, he has already actualized his vision in the poem. Campo di Fiori is the new Campo di Fiori. The act of telling has transformed the lonely deaths of the Ghetto Jews and the death of Giordano Bruno into a "legend," that is, a building block of folklore that cannot be forgotten. Thus, the poet's inclusive universal perspective teaches empathic attention to suffering at large.

In contrast, A Poor Christian Looks at the Ghetto rejects the inclusive humanistic universal message in Campo di Fiori. More specifically, it revokes the underlying syllogism that places the event of the Jewish genocide on the continuum of human history. Since the indifference of the joyful Polish crowds on Krasińskich Square recalls the indifference of the carefree Italian crowds on the Campo di Fiori, and since the loneliness of the Ghetto inhabitants reechoes the loneliness of Giordano Bruno, therefore the burning of people in the Ghetto is qualitatively comparable to the burning of Giordano Bruno at the stake. This logical reasoning characterizes the liquidation of the Ghetto as yet another forgotten story of human suffering. From his standpoint of an objective observer, the poet of Campo di Fiori, functioning as humanity's reformer, restores to history both, and, by extension, all cases of forgotten suffering.

The apocalyptic vision of the Ghetto in A Poor Christian Looks at the Ghetto defies the treatment of the Jewish genocide as a historical event. Unlike the detached observer-speaker in Campo di Fiori, the first-person speaker is unable to control his feelings. He is engulfed by a sense of 
dread; it is the overriding terror of looking at the end of world as he has known it. Even though his Christian identity keeps him physically safe on the "Aryan side" of the city, his imagination has been taken prisoner by the horror of the burning Ghetto: it drags him to the site of the destruction, impels him to contemplate the devastation, and confronts him with the ramifications of the Jewish disaster for the Christian world.

Irresistibly drawn to the scene behind the wall, the speaker "sees" the destruction of the place that used to be inhabited by humans. His imagination makes him witness the complete disintegration of the material Ghetto. He watches the relentless process of "the tearing, the trampling on silks.../ the breaking of glass, wood, copper, nickel, silver, foam./ Of gypsum, iron sheets, violin strings, trumpets, balls, crystals/...Torn is paper, rubber, linen, leather, flax." What eventually remains is "only the earth, sandy, trodden down/ With one leafless tree." The destruction opens the burned Ghetto to bees and ants, which have already begun to prosper on the remains of human bodies - "red liver," "the honeycomb of lungs," "white bone" (Polonsky, 1987, 51).

While the world of the Jews has been taken over by insects, the underworld fills up with their ashes. The Christian speaker, who, unlike Dante, has no Virgil to guide, teach, and protect him in the world of the dead, surrenders to his awe-stricken imagination, which conjures up a hellish underground mock-funeral of the burned Jews.

The semblance of a burial is performed by a "guardian mole" with "a small lamp fastened to his forehead." He "has swollen eyelids, like a Patriarch," who has gained his knowledge from "reading the great book of the species," presumably the Book of Genesis. ${ }^{10}$ With the physical disappearance of the Jews, the Patriarch, most probably Abraham, father of the Jewish people, ${ }^{11}$ has transformed into an underground mole guarding the piles

${ }^{10}$ The name of the Book of Genesis in Polish is Księga Rodzaju, that is, the book of species. Since the poem tells us that the Patriarch studied "wielką książkę gatunków," the great book of the species, and since "rodzaj" (species) is the synonym of "gatunek," I believe it is safe to conjecture that the Patriarch studied the Book of Genesis, and especially the story of Creation.

${ }^{11}$ Even though there were three Patriarchs, Abraham, Isaac, and Jacob, I assume the reference here is to Abraham, the first Patriarch and the first to receive the promise of becoming the father of the Jewish people. 
of Jewish ashes. The ashes tell the final chapter in the history of the nation that began in the great book of the species and that made him Patriarch. Thus, the guardian mole "touches burned bodies, counts them, pushes on, / He distinguishes human ashes by their luminous vapor,/ The ashes of each man by a different part of spectrum." The absurdity of categorizing ashes denotes the Jews' return to the pre-creation state of non-being. Whereas the first man was formed "out of dust," was given "the breath of life," and was identified by the name of Adam, the Holocaust of the Ghetto Jews undid the act of creation: while the suffocating smoke deprived them of breath, the fire obliterated their names by turning their bodies into the dust of ashes.

The decree of the Final Solution segregated the single human species, which descended from Adam, into the Jewish species which must die, and the Christian species, which will live. If only Christians are allowed to live, then the Christian speaker's being attests to the non-being of Jews. Captured alive with the ashes of the burned Jews, the Christian witness gains the consciousness that his body has become undeniable proof of the "un-provable" murder of the Jews. This realization makes him exclaim with horror, "I am afraid, so afraid" of the guardian mole, who "will count me among the helpers of death:/ The uncircumcised." The speaker's real fear of the imagined indictment as an enabler of the Jewish murder reflects his overwhelming sense of terror: his destiny to live has been determined by his Christian origins that he shares with the perpetrators of the Jewish genocide. In a horrific reversal of all moral values, the Christian origins of an uncircumcised witness of the Final Solution with the uncircumcised perpetrators of the Final Solution determine the witness' affiliation with murderers.

The fearful sense of guilt at having affinity with the murderers of the Jews forfeited the self-image of the witness as a virtuous Christian. And in another horrific ironic twist, the genocide of the Jews also deprived him of the grace of eschatological deliverance. Identifying himself as "I, the Jew of the New Testament,/ Waiting two thousand years for the second coming of Jesus," the Christian speaker realizes that the expectation of the Messiah has been consumed by the fires that burned the Jewish people out of history. As a "circumcised," Jesus has become the victim of the Final Solution, the fire turning his body into ashes, erasing his messianic identity 
and putting an end to the hope for his return. In this sense, as the title of the poem indicates, the Christian who looks at the Ghetto is indeed poor: the murder of the Jews not only diminished his Christian self, but also ended his hopes for salvation.

As this discussion has shown, A Poor Christian Looks at the Ghetto needs to be read in the context of Miłosz's letters to Andrzejewski and, consequently, in light of Campo di Fiori. The conceptual transition from Campo di Fiori to A Poor Christian Looks at the Ghetto signals the poet's evolving comprehension of the ramifications of the Jewish extermination for the Christian world, and, more specifically for the Polish Catholics who eye-witnessed the genocide. Campo di Fiori, with its call for an empathic recognition of an estranged sufferer, be it a Ghetto Jew or Giordano Bruno, speaks of mending the altruistic aspect of humanity at large. A Poor Christian Looks at the Ghetto focuses on the Jewish genocide and its dire implications for the Church's mission.

Despite the Nazi plan to "liberate" the world from Jewish presence and memory, the Final Solution did not disconnect the Christians and the Jews. On the contrary, the theological consequences of the genocide bound the Jewish victims and the Christian witnesses in an impossible knot of mutual negation. The willful burning of the Jews of the Old Testament by his Christian co-religionists revoked the claim of the Christian speaker in A Poor Christian Looks at the Ghetto, the "Jew of the New Testament," to Jesus' gospel of atonement, forgiveness, and love. The disappearance of the Jews deprived Christian witness of the grace of caritas. And therefore, even though in his letters Miłosz tried to defy his Catholic identity by repudiating Catholicism as "a desiccated mummy," his speaker recognizes that he has been imprinted with the Church's spiritual barrenness; the moral turpitude of the Church, which enabled the Jewish genocide, has tainted his Christian identity.

\section{Holy Week: A Failed Attempt to Save Christian Love}

Like Miłosz, Andrzejewski was preoccupied with the ethical validity of the Catholic Church in times of terror. As attested by his letters, even in the midst of despair about the moral collapse of the world, Andrzejewski 
strove to maintain his confidence in Catholicism and its teachings of love. He believed that the Church's continuing relevance was predicated upon the restoration of loving solidarity of human beings, all God's creatures. In Holy Week, however, Andrzejewski's insistence on the redemptive potency of Catholicism in the time of Jewish genocide proved untenable. The defeat of the advocates of Christian love for Jews by ardent Christian haters of Jews communicates the writer's recognition of the Catholic believers' surrender to genocidal evil.

Holy Week takes place on the "Aryan side" of Warsaw, and, as the title indicates, during the week of Easter. The concurrently unfolding Ghetto Uprising dominates the city. Frequent references to the explosions and the sounds of fighting, the heavy smoke arising from the Ghetto that covers the sky during the day, and the glow of the fires that illuminate the night underscore the relentless Jewish destruction. The horror becomes even more palpable with the appearance of Irena, a desperate and dispirited fugitive Jewish woman searching for a hiding place. Irena runs into Jan Malecki, her former boyfriend, at the wall of the Ghetto. Jan brings Irena to the apartment where he lives with his wife, Anna, a deeply believing Catholic, who is in advanced stages of pregnancy.

The presence of Irena centers the narrative on Polish responses to the Jewish situation. Malecki, an intellectual liberal, who is reluctant to get engaged with the Jewish plight, is conflicted about giving shelter to Irena, whose "bad looks" exacerbate the danger of denunciation. In contrast, Malecki's idealistic younger brother Julek and his young friend are prepared to risk almost certain death when they rush to help the Ghetto fighters. Other characters, meanwhile, consider the mass murder of the Jews, even though gruesome, a positive development for the postwar Poland; they claim that the Germans are solving Poland's prewar "Jewish problem" without implicating the Poles in the murder. Polish children, however, demonstrate the morally corrupting impact of the genocidal reality when in a horrific scene they denounce a Jewish fugitive boy from the Ghetto to a German policeman who executes the boy on the spot. All along, as part of Easter celebrations, a sky-carousel and an amusement park are being constructed at the Ghetto walls on Krasińskich Square, while passersby occasionally mock the fighting Jews, but for the most part remain altogether indifferent to the Ghetto events. 
This discussion of Holy Week focuses on the plot line concerned with Anna's failed battle for the soul of Christianity in the reality of the burning Ghetto. The allusion to the Virgin Mary in Anna's pregnancy and the context of the Holy Week of Easter underline the theological signification of Anna's stance. The horror of the burning Ghetto threatens the Christian ethos of redemption enshrined in the miraculous birth of Jesus and the divinity of his self-sacrificial atonement for the world.

As Anna sees it, the moral integrity of the Christian faith is conditioned upon extending Christian love to the suffering Jews. Anna alludes obliquely to her position already in her conversations with Jan. When Jan doubts her approval of his decision to bring Irena to their home, she responds with considerable bitterness, "Do you really know me as little as that?" (Miłosz, 2007, 31) And when Jan expresses his reservations about extending help to the fighting Ghetto, claiming, "Haven't enough of us [Poles] died already," she objects, claiming that "It is not the same thing" as the suffering of the Jews "over there" (Miłosz, 2007, 53, 36), namely, in the burning Ghetto. Furthermore, though fearful about the risk Julek is taking, Anna is proud and supportive of his decision to engage in helping the fighting Ghetto.

In the stream of consciousness that follows, Anna unequivocally reaffirms her conviction about the utmost importance for the Christians to help the perishing Jews. She believes that the destruction of the Jews undermines "the eternal sense and order in the world" bestowed upon humanity by the Christian teachings of love. This order is now imperiled by the "unimaginable sufferings, humiliations, and wrongs" inflicted upon the Jewish people, and, in this sense, the suffering of the Jews has become "the most painful test for a Christian conscience." The Jews have already suffered "for many centuries" under the Church for having refused to accept Jesus. Hence, helping Jews in the current circumstances is not a matter of choice. It is rather the moral obligation of Christians to act according to Jesus' gospel of love and extend help to the suffering Jews. "Who, if not a Christian," Anna asks, "ought to do everything in his power to lighten the misfortune of these downtrodden people and be with them, as they died alone and without hope?" (Miłosz, 2007, 53).

As the evolving relationship between Anna and Irena demonstrates, Anna's question is not theoretical; in fact, she is fully ready to act on her vision of a true Christian. In the scene in which Anna shares with Irena the 
story of her terrible losses of family members under the occupation, Irena, out of despair, bitterly deplores the senselessness of all such deaths. At this point, Andrzejewski, the author, makes Anna, his character, reiterate practically verbatim the statement in his letter to Miłosz that even though he cannot fathom it, he has deep belief in the meaning of the present-day reality of terror. Thus Anna responds to Irena's desperation, "I do believe... that everything has to have meaning even though we may not always know what it is" (Miłosz, 2007, 66). In fact, Anna does know what the meaning of the present situation is. She realizes that the unexpected arrival of Irena, a Jewish fugitive has given her the chance to actively fulfill the obligation that Jewish suffering has presented to the Christian conscience. The moral injunction to help Irena is proof of the providential design to extend Christian caritas to the suffering Jews.

Anna embarks on actualizing the providential intent when she proposes to "place Irena in Grotnica, the old Cisterian cloister," where, "behind the walls of the medieval monastery" she will find "an ideal haven" (Miłosz, 2007, 111). As an act of love, saving Irena, a Jewish person, behind the safe walls of the monastery will atone for the centuries of Jewish suffering inflicted by the Church. At the same time, putting into practice the Church's teaching of love will forcefully confront the genocidal evil of the perpetrators.

It is therefore tragically ironic that Anna's redemptive project is dealt total defeat when she is on her way to church to observe Good Friday. Before reaching the church, she stops at the military cemetery to pray for Julek's safety. As the baby moves inside her, Anna feels both guilty and happy that "in the midst of all this human suffering, death and injustice... she carried within her, in defiance of the annihilation taking place all around, this new creation, this hope of future joy" (Miłosz, 2007, 115). Despite her "panic and conflict of feelings," she prays "for a merciful fate." The act of prayer signals her faith in providential order; it attests not only to her conviction that her prayers are being heard, but also that mercy is possible even under the clouds of smoke arising from the burning Ghetto.

The powers of ancient Christian hatred of Jews, which take over at this particular moment, ruthlessly destroy Anna's plans, dispelling the providential meaning that she attributed to Irena's appearance. Mrs. Piotrowski, a simple, vulgar woman, a smuggler and a marketeer, whose younger 
husband is a "typical Warsaw rake" (Miłosz, 2007, 113), does not keep her resentment of Jews secret. While her husband is planning to take advantage of Irena's helpless situation and rape her, Mrs. Piotrowski, who harbors visceral hatred for the Jewish woman, wants to get rid of her by all means and at any cost.

In her previous conversation with Anna, she makes her uncompromising position about Jewish fugitives clear, "In my opinion... any Pole who hides a Jew in his house is... nothing but a swine! I'm a Pole and that's what I say!... It's unchristian for good Catholics to have to die for a single solitary Jew. That simply cannot stand" (Miłosz, 2007, 62). Mrs. Piotrowski's view of the role of a Christian at the time of the Jewish genocide contradicts Anna's conviction of the power of Christian caritas. Unlike Anna, who sees the self-sacrifice of hiding Jews as the ultimate test of Christian conscience, Mrs. Piotrowski defines hiding Jews as unchristian. Her position derives from the Christian theology of contempt that historically condemned Jews to abject misery and endless persecutions. Mrs. Piotrowski, who sees herself as a Pole and a "good Catholic," has no qualms about validating the Christian tradition of hatred in the present situation. In fact, she considers it her unquestionable right and responsibility to protect Polish society not only from fugitive Jews, but also from the Poles who shelter them, and who, as she sees it, are neither true Poles, nor good Catholics, but "swine." Thus, Mrs. Piotrowski acquiesces not only with the Nazi decree of Jewish extermination, but also with the edict of death sentence for Poles who assist Jews.

Though she asserts, "I'm not one to go to the Gestapo, I don't want anyone's blood on my hands" (Miłosz, 2007, 93), Mrs. Piotrowski's vociferous exposure of Irena's Jewish origins outside the building, in full daylight and in front of a crowd neighbors and passersby, ineluctably portends Irena's death sentence. With practically no objection raised by the spectators, who either stare, or look away, she humiliates Irena, challenging her to admit that she is "a filthy Jew." Then she orders Irena to leave, as she yells, "Get out of here! Back to the ghetto with you. That's where kikes like you belong." Irena knows she must leave, but she does not go in silence. All of a sudden she "felt a blind, violent hatred well up inside her," which makes her curse Mrs. Piotrowski and the crowd, "And may the rest of you all die like dogs!" May you all burn just like us. May they 
shoot each and every one of you! I hope they murder you all!" Then "[s]he quickly turned around, and in the deathly silence that ensued, she started walking slowly toward the gate" (Miłosz, 2007, 124).

The exchange seems to underscore the unmitigated animosity between Polish witnesses and the Jewish victims that will not relent even in the reality of the burning Ghetto. Unlike Anna, whose compassion and empathy drew Irena into a relationship based on dignity and hope, Mrs. Piotrowski has no qualms sending Irena back to hopelessness, degradation, and death. At the same time, ironically, Irena's curse is not merely an outburst of helpless rage: it is both a testimony of the atrocities inflicted on Jews and a prediction of a possible Polish fate. But even though the rumors about the forthcoming annihilation of the Polish people were widely spread and generally believed, the crowd's silence, uninterrupted by any attempt to stop Irena on her way to certain death, attests to complete lack of empathy for the victim. Despite the likelihood of sharing the same fate, nobody in the Polish crowd signals a measure of solidarity with Jewish suffering. The unanimous silence speaks loudly of the witnesses' endorsement of the Jewish genocide. In contrast with Anna's search for the divine providence in Christian love, the mainstream acceptance of the Jewish fate demonstrates the providential nature of the Final Solution. Whereas the physical obstacle of the Ghetto walls blocked the evidence of the crime, the willing cooperation of the Polish Catholic public with the prohibition of sheltering Jews assured the totality of the Jewish extermination.

\section{Conclusion}

As the above discussion has shown, Miłosz and Andrzejewski's wartime correspondence and literary writings projected the writers' evolving comprehension of the moral implications of the Jewish genocide. The fictional and, therefore, subjective representations of life under the cloud of the burning Ghetto demonstrate a shift away from the 1942 correspondence, which reflected the writers' conceptual examination of the world's moral crisis and their search for ways to bring about moral repair. The 1943 writings express a growing certainty about the ineffectiveness of the virtues of reason and caritas as means to fight genocidal evil. The 
writers' representations of the emotional responses to the burning Ghetto - the carefree crowds amusing themselves in front of the Ghetto, the fearful Christian looking at the Ghetto, the failed attempt to save a Jew - indicate the ways in which the genocidal evil has irrevocably invaded the witnesses' daily life, and therefore the writers' lives as well. Miłosz's and Andrzejewski's thinly disguised self-characterizations as, respectively, the "poor Christian," who loses his sense providential protection, and "Anna," who fails to reaffirm the providential plan to repair the world, denote the writers' consciousness of being personally implicated in the moral predicament of the Jewish genocide. Their literary imagination arises from the recognition that as human beings they bear the responsibility for their fellow human beings murderous evil.

The ethical-theological conclusions of the Catholic writers, who eyewitnessed the horrific collapse of the a priori moral fundamentals of the human society have been ignored by the continuing and intensifying proclivity to promote an alternative history of the Jewish genocide in Poland. Thus the problem of coming to terms with the Holocaust does not consist in rejecting the Jewish memory, but rather in denying the contesting memory of Polish Catholics who witnessed the moral failure of their compatriots. It is their courage to face the truth that should be celebrated and written into history.

\section{References}

Allen, R.E. (1959). Anamnesis in Plato's Meno and Phaedo. "The Review of Metaphysics" vol. 13, no. 1, p. 165.

Andrzejewski, J. (1987). Z dnia na dzień. Warszawa: Biblioteka "Więzi".

Austin, M.W. (2013). Kierkegaard: Understanding the Christian Father of Existentialism. "Christian Research Journal" vol. 36, no. 3.

Błoński, J., Edelman, M., Miłosz, C., Turowicz, J. (2012). Campo di Fiori' Fifty Years Later: The People Who Remain. Trans. J. Gromek-Illg, "Polin" vol. 24, p. 414.

Chmielewska, K., Molisak, A. (eds.) (2017). Monuments of Memory: Places of Oblivion (Pomniki pamięci: Miejsca niepamięci). Warszawa: Instytut Badań Literackich PAN.

Czarnecka, E., Fiut, A. (1987). Conversations with Czestaw Mitosz. Trans. R. Lourie. San Diego: Harcourt Brace Jovanovich.

Distorting and Rewriting the History of the Holocaust in Poland: The Case of the Ulma 
Family Museum of Poles Saving Jews during World War II in Markowa. (2017). "Yad Vashem Studies" vol. 45, no 1, pp. 29-60.

Freud, S. (1930). Civilization and Its Discontents. London: The Hogarth Press.

Miłosz, C. (2005). Legends of Modernity: Essays and Letters from Occupied Poland, 1942-1943. Trans. M.G. Levine. New York: Farrar Strauss Giroux.

Miłosz, C. (2007). Holy Week: A Novel of the Warsaw Uprising. Trans. O.E. Swan and Students. Athens: Ohio University Press.

Polonsky, A. (ed.) (1987). Polin: Studies in Polish Jewry. Liverpool: Liverpool University Press.

Polonsky, A. (ed.) (1990). My Brother's Keeper? Recent Polish Debates on the Holocaust. London: Routledge.

Rourke, T.R., Chazarreta Rourke, R.A. (2007). The Theory of Personalism. Lanham: Lexington Books.

Williams, T.D. (2004). What is Thomistic Personalism? "Alpha Omega" VII, no. 2, pp. 192-197.

Wojtyła, K. (1963). Introduction. In: J. Turowicz. Chrześcijanin w dzisiejszym świecie. Kraków: Wydawnictwo Znak, pp. 8-9. 